\title{
ResearchArticle
}

\section{Studies on correlation and path analysis in germplasm of Indian mustard [Brassica juncea (L.) Czern and Coss.]}

\author{
Dinesh Awasthi, V. K. Tiwari and V. S. Kandalkar
}

\begin{abstract}
SUMMARY
Studies on correlation revealed that seed yield per plant and harvest index exhibited significant positive correlation and both traits also demonstrated significant positive correlation with days to 50 per cent flowering and number of secondary branches per plant at both genotypic and phenotypic level. This indicated the strong association of seed yield per plant, harvest index, days to 50 per cent flowering and number of secondary branches per plant. Both genotypic and phenotypic correlation co-efficient for seed yield per plant was found significant positive correlation with days to 50 per cent flowering, number of secondary branches per plant, number of siliqua per plant and harvest index. Number of siliqua per plant was found significant positive correlation with number of primary branches per plant, number of secondary branches per plant, number of siliqua per plant and seed yield per plant. Number of secondary branches per plant was found significant positive correlation with days to 50 per cent flowering, number of primary branches per plant, number of siliqua per plant, number of seeds per siliqua, seed yield per plant and harvest index. Further, the path co-efficient analysis showed low residual effect (0.00482, 0.00304 and 0.00167) during Rabi 2016-17 and 2017-18 indicating that most of the major yield components were included in the study. Harvest index percentage had the highest direct positive effects on seed yield per plant, number of siliqua per plant, number of seeds per siliqua, number of secondary branches per plant and days to maturity. Based on result it has been concluded that two traits namely seed yield per plant and harvest index exhibited significant positive correlation as well as direct effect on seed yield may be considered for selection and to improve the seed yield of the mustard germplasm.
\end{abstract}

Key Words : Correlation, Path analysis, Indian mustard (Brassica juncea L.)

How to cite this article : Awasthi, Dinesh, Tiwari, V. K. and Kandalkar, V. S. (2020). Studies on correlation and path analysis in germplasm of Indian mustard [Brassica juncea (L.) Czern and Coss.] . Internat. J. Plant Sci., 15 (2): 101-106, DOI: 10.15740/HAS/ IJPS/15.2/101-106, Copyright@ 2020: Hind Agri-Horticultural Society.

Article chronicle : Received : 07.04.2020; Revised : 20.05.2020; Accepted : 06.06.2020

\section{MEMBERS OF THE RESEARCH FORUM}

Author to be contacted :

V.K. Tiwari, AICRP-Soybean (ICAR), Rajmata Vijayaraje Scindia Krishi Vishwavidyalaya, Zonal Agricultural Research Station, Morena (M.P) India

Email : vkt786@rediffmail.com

Address of the Co-authors:

Dinesh Awasthi and V.S. Kandalkar, Department of Plant Breeding and Genetics, College of Agriculture, Rajmata Vijayaraje Scindia Krishi Vishwavidyalaya, Gwalior (M.P.) India 